Maurer School of Law: Indiana University

Digital Repository @ Maurer Law

2005

\title{
Migrating Towards Minority Status: Shifting European Policy Towards Roma
}

Timothy W. Waters

Indiana University Maurer School of Law, tiwaters@indiana.edu

Rachel Guglielmo

Open Society Institute

Follow this and additional works at: https://www.repository.law.indiana.edu/facpub

Part of the Human Rights Law Commons, and the International Law Commons

\section{Recommended Citation}

Waters, Timothy W. and Guglielmo, Rachel, "Migrating Towards Minority Status: Shifting European Policy Towards Roma" (2005). Articles by Maurer Faculty. 323.

https://www.repository.law.indiana.edu/facpub/323

This Article is brought to you for free and open access by the Faculty Scholarship at Digital Repository @ Maurer Law. It has been accepted for inclusion in Articles by Maurer Faculty by an authorized administrator of Digital Repository @ Maurer Law. For more information, please contact rvaughan@indiana.edu. 


\title{
Migrating Towards Minority Status: Shifting European Policy Towards Roma*
}

\author{
RACHEL GUGLIELMO \\ Open Society Institute \\ TIMOTHY WILLIAM WATERS \\ University of Mississippi Law School
}

\begin{abstract}
During the 1990s, European policy towards Roma evolved from concern about migration toward rhetoric about rights. In this article we trace that shift across two OSCE reports. Following rhetorical-action models, we show how the EU's commitment to enlargement and 'common values' compelled it to elaborate an internal approach to minority protection. Concerns about migration persist, but Europe now has to consider how to integrate Roma as minorities.
\end{abstract}

\section{Introduction}

Roma have wandered the borderlands of social legitimacy since their arrival in Europe centuries ago. Policies towards Roma in most European states have long been defined by majorities' perceptions of Roma as outsiders. Despite a long history of settlement and co-existence, Roma remain the quintessential migrant group. Yet since the early 1990s there has been an evolution in European institutions' policy towards Roma, from an open concern with the potentially destabilizing effects of westward migration to an increasing rhetorical emphasis on discrimination and positive minority rights. In this article, we trace the shift in two major reports addressing the situation of Roma drafted by one of the pre-eminent European institutions addressing minority issues during the 1990s,

* The authors would like to thank Alphia Abdikeeva, Martin Kovats, Diane Orentlicher, John Packer, Nidhi Trehan and the referees for their thoughtful comments and suggestions on drafts of this article. The article represents the views of the authors alone, and not necessarily the views of the Open Society Institute. 
the High Commissioner on National Minorities (HCNM) of the Organization for Security and Co-operation in Europe (OSCE). ${ }^{1}$ We examine the reasons why this shift took place and what it has signified in practical terms for the Roma and for European minority protection policy more broadly.

Rhetorical-action and deliberative models of policy formation (Schimmelfennig, 2001; Neyer, 2003; Piana, 2004) are followed to demonstrate how the expansion of the European Union (EU) to include the countries of central and eastern Europe (CEE) effected a dynamic change in policies towards both migrants and minorities. The article argues that, although the EU and other European institutions were initially concerned with externally oriented migration control, the fact that the case for enlargement was articulated in terms of 'common values' (Schimmelfennig, 2001) compelled EU Member States to elaborate a more internally oriented, rights-based approach to minority protection and towards Roma. Concerns about migration, security and integration that surfaced at the beginning of the accession process persist, but minority protection has decisively entered European policy and Europe's self-image. It will become increasingly necessary to address Romani issues in a different register; in the light of this, prudent policy will consider not if, but how, Roma will be integrated into Europe as minorities.

Given their generally extreme marginalization, ${ }^{2}$ for many Roma a successful conceptual move from disregarded outsider to constitutive participant - from migrant to minority - could represent progress, even as material conditions continue to be extremely difficult for Romani communities in most countries (EUMAP, 2002). For Europe, a well-articulated minority protection policy could contribute to greater security and stability. The interaction between

\footnotetext{
${ }^{1}$ The HCNM reports are a useful framing device for examining trends in European minority policy. First, the reports were influential in policy formulation in other institutions: the European Commission relied on the HCNM and the Council of Europe in preparing its regular reports on accession, for example, while the HCNM's 2000 report recommendations formed one of the bases for the guiding principles adopted by the European Council at Tampere (Cocen Group, 1999). Second, the fact that a single institution produced these two reports at the beginning and latter stages of the accession process allows us to inquire into ways in which rhetoric and policy changed and interacted during the 1990s.

${ }^{2}$ Nothing in this article assumes a monolithic identity for Europe's Roma, or for its majority populations. Some Roma are assimilated, others marginalized; some are poor, others wealthy; some are illiterate, others have doctorates. When we speak of Roma, we encompass that diversity, allowing that many Roma challenge a common identity and even that 'Roma' as a constructed category conceals as much as it explains. At the same time, nothing is gained by a sterile and paralytically correct formalism that incessantly invokes heterogeneity against all generalization. Roma are extraordinarily diverse and share certain features about which we may usefully say certain things, while refusing to do so has costs - making it difficult to say anything meaningful about discrimination or to derive meaning from the observation that most (though not all) Roma have dramatically lower levels of education, employment, wealth and life prospects than most (though not all) members of the majorities with which they live (see Hancock, 'Foreword', in Guy, 2001, p. ix). Finally, it is demonstrable that majority populations do in fact generalize about Roma; this 'negative' ascription of common identity has important social and policy implications even if many Roma resist it (Waters, 1995, pp. 25-6, 39-41; Lucassen et al., 1998, p. 6). However inaccurate such ascription may be, predictions about policy must take it into account; this article does so.
} 
rhetoric and policy from the early 1990s to the closing days of accession suggests such expectations are not unwarranted, although policy-makers still confront questions about the interrelatedness of rights, investment and security approaches, practical questions about the relationship of those models to funding priorities, and questions about the role of intention and social attitudes in shaping policy.

\section{Roma: Migrating toward Minority Status}

Europe's highly diverse communities of Roma have been moving from migrant to minority status only very slowly and with many setbacks. An historical review of policies towards Roma reveals a strong security-oriented bias; though differing in method, most policies have shared the basic aim of controlling populations viewed as alien, untrustworthy and destabilizing.

Ancestors of the Roma migrated into Europe from northern India from the eleventh to the fifteenth centuries. Their origins were unknown to but clearly distinct from those of the European peoples among whom they settled. Contemporary European images of Roma as permanent migrants may be traced in part to the hostile response their presence and difference provoked: some observers have asserted that the mobility and insularity of some Romani communities has been a way of preserving identity in an uncertain, non-Romani environment (Council of Europe, 1999; Hancock, 1999). At the same time, cultural differences between Romani and majority communities have prompted some degree of voluntary separation and have sometimes also given rise to conflict (Pogány, 2004, pp. 26-30; Lucassen et al., 1998, p. 9). Even after permanent Romani settlements became the norm, especially in central and eastern Europe, exclusion of the 'migratory outsider' remained a self-justifying policy.

When concepts of minority rights gained currency in the nineteenth and early twentieth centuries and the inter-war period, some Roma seized the opportunity to organize themselves (Crowe, 1994, p. xiv). However, traditional minority protection policies were not designed with Roma in mind, and the benefits Roma derived were peripheral to those policies' purpose. ${ }^{3}$ In post-war socialist systems in particular, Roma - who lacked a kin state - were often categorized as 'ethnic' rather than 'national' minorities, a distinction relegating them to a secondary minority status with less preferential treatment, despite in many instances being as 'old' and long-settled as other communities. ${ }^{4}$ In any

\footnotetext{
${ }^{3}$ None of the major instances of minority protection in European history - the Treaty of Westphalia, the Ottoman millet, the Congress of Vienna, the inter-war minority regimes - afforded rights to Roma, or even contemplated them as subjects (see Hannum, 1990, pp. 50-4).

${ }^{4}$ Inter-war Czechoslovakia's 'criterion for recognizing its various ethnic minorities rested upon whether they were represented by a nation state or not ... . Roma did not, despite being one of the largest minority populations in Czechoslovakia, because there was no Romani homeland' (Hancock, 1999).
} 
case, the benefits proved an insufficient corrective to dominant perceptions of Romani difference as a threat, to discrimination and exclusion arising from that perception, and to policies designed to eliminate that difference or their presence altogether. ${ }^{5}$ This context is crucial to understanding the often sceptical stance towards 'Roma policies' among Roma, (Council of Europe, 1999, para. 18) and the emphasis Romani leaders place on meaningful participation in policy-making processes (Mirga and Gheorghe, 1997; Klimová-Alexander, 2005, pp. 121-3).

\section{The HCNM Reports}

At the outset of enlargement in the early 1990s the European Community (EC) had no minority policy of its own. However, EC Member States were concerned about ethno-national conflicts in some CEE candidate states and the possibility of migration flows into the EC. ${ }^{6}$ Both issues implicated minority populations. Lacking a legal and policy framework to address these issues, the EC took two significant steps. First, it included 'respect for and protection of minorities' in the Copenhagen criteria for accession adopted by the European Council in June 1993 (Copenhagen Criteria, 1993, Sec. 7.A.iii). These applied only to candidates, so the EC was able, at least initially, to develop a minority policy for candidate states without affecting policy within the EC.

Second, the European Commission relied on the OSCE (formerly the CSCE) and the Council of Europe $(\mathrm{CoE})$ in developing its policy (Hughes and Sasse, 2003, pp. 7-19; Vermeersch, 2003, p. 8). Both organizations had engaged in a flurry of standard-setting on minority rights immediately following the fall of the Berlin Wall, ${ }^{7}$ and both had focused on applying and implementing these standards in the CEE region. Resort to these institutions was thus consistent with and reinforced the EU's determination to engage minority issues in candidate states without developing its own minority policy - and its determination to deal with the question of minorities before accession and outside the Union.

\footnotetext{
${ }^{5}$ In the past, policies to eliminate Romani difference have included: forced removal of children from families; criminal penalties for speaking Romanes; citizenship and pass document restrictions; and forced resettlement and assimilation. Policies to eliminate Roma entirely have included: expulsion and deportation; bounties for killing Roma; forced sterilization; medical experimentation; and the Nazi genocide. For comprehensive histories of policy towards Roma, see Crowe and Kolsti (1991); Kenrick and Puxon (1972); for brief surveys, see Kenrick (1998, pp. 1-7); Fraser (2000, pp. 17-31).

${ }^{6}$ See Council of the European Community (1991); European Council (1992). The European Community became the European Union on 1 November 1993.

${ }^{7}$ The CSCE became the OSCE on 21 December 1994. The Council of Europe adopted the Charter for Regional or Minority Languages (CRML) in 1992, Recommendation 1201 (1993) and the Framework Convention on National Minorities (FCNM) in 1994. The CSCE adopted several documents that addressed minority issues in general, such as the Charter of Paris (CSCE, 1990a), and Roma in particular, including the Copenhagen Document (CSCE, 1990b), the Moscow Document (CSCE, 1991a), the Geneva Report (CSCE, 1991b), and the Helsinki Document (CSCE, 1992).
} 
When the HCNM first addressed the situation of Roma in 1993, EU enlargement was just getting underway; western European states were concerned about the possibility of massive and potentially destabilizing migration by Roma from CEE states, a concern reflected and prioritized in the HCNM's report. By 2000, when the HCNM issued his second report on the Roma, CEE states were just steps away from accession; this second report does not address migration, instead placing strong emphasis on advancing human rights, fighting discrimination and promoting effective participation in public life.

\section{The HCNM Report of 1993}

By April 1993, only months after the HCNM took office, ${ }^{8}$ the OSCE committee of senior officials (on which all EU states are represented) had already requested him to:

study the social, economic and humanitarian problems relating to the Roma population in some participating States and the relevance of these problems to the Mandate of the High Commissioner ... and to report thereon to the Committee of Senior Officials through the Chairman-in-Office. (HCNM, 1993, p. 2)

This seems a curiously high level of concern, given the HCNM's mandate for conflict prevention: was an international conflict involving Roma imminent, or were Roma engaging in violent protests that could affect 'peace, stability or relations between participating States'? ${ }^{9}$ In his September 1993 report, the HCNM seemed to anticipate such questions:

In the discussion [with the Committee], it was furthermore stated that these problems, which fall into the larger category of migration problems, could also have an international dimension. (HCNM, 1993, p. 2; emphasis added)

The allusion to internal discussions suggests that concerns about Roma migration from the CEE states into western Europe in fact constituted the primary motivation behind the Committee's request. ${ }^{10}$ This interpretation is borne out by the report itself. Though going beyond the 'social, economic and humanitarian' situation of Roma to discuss discrimination and violence, the report was careful to present these problems in the light of the Committee's implicit concern:

The aim, in short, should be to improve the 'quality of life' in migrationproducing countries (and areas within those countries) for the sake of such

\footnotetext{
${ }^{8}$ The first HCNM, Max van der Stoel, was appointed in December 1992 and took office in January 1993.

${ }^{9}$ The HCNM should "provide "early warning"... at the earliest possible stage in regard to tensions involving national minority issues that have the potential to develop into a conflict within the CSCE area, affecting peace, stability, or relations between participating States' (CSCE, 1992, emphasis added).

${ }^{10}$ Even the formulation concerning migration does not obviously fall within the plain meaning of the HCNM's mandate - an example, in a European but non-EU setting, of 'creeping competence' (Pollack, 1994).
} 
improvements, but also for the reduction in pressures on international migration. In addition to commerce, investment, and development assistance leading to economic opportunity, efforts at addressing the specific problems of the Roma, including discrimination and violence against them, will contribute considerably to improving their 'quality of life.' Such efforts are likely to encourage people to continue their lives where they already are. (HCNM, 1993, p. 11, emphasis added) ${ }^{11}$

Formally, the report addressed all OSCE states. However, it focused on 'migration-producing countries', even though similar patterns of exclusion, violence and discrimination could have been traced in western European countries (EUMAP, 2002; ERRC, 1996, 2000, 2003); it advised countries on the receiving end of migration to ensure they had humane refugee policies (HCNM, 1993, pp. 14-15). The report clearly responds to the Committee's underlying interest: not conflict prevention, but migration prevention.

In several respects, however, the HCNM went beyond a narrow interpretation of the Committee's interests, contributing to important changes in the way minority issues would come to be spoken of in European institutions. First, the fact that the Roma - as noted above, traditionally an 'ethnic minority' - were the subject of a report by the High Commissioner on National Minorities sent a strong signal that there would not be any distinction in treatment accorded to ethnic as opposed to national minority groups - at least in the CEE region. This approach already prevailed in theory (Capotorti, 1979, p. 119) but, in practice, classification of Roma as an ethnic minority had continued in many CEE states ${ }^{12}$ and some EU members as well. ${ }^{13}$ Partly due to pressure from the HCNM and other European institutions, such distinctions have been eliminated from most CEE Roma and minority policies.

Second, though the Committee had requested assessment of the 'social, economic and humanitarian problems' of Roma, the 1993 report also showed how Romani migration could be triggered by civil and political rights violations as well as socio-economic marginalization and recommended 'implementation of civil, political, economic, social, and cultural rights and the strengthening of democratic institutions and the rule of law' (HCNM, 1993, p. 14). These issues were also placed in the context of migration; still, by highlighting 'rights' as well as 'problems', the report presented Roma as rights-bearing individuals

\footnotetext{
${ }^{11}$ The report also notes that, in addition to economic opportunity, 'quality of life' includes an 'enduring sense of belonging' and 'greater confidence in the capacity of government authorities to protect human rights, ensure the rule of law, and promote tolerance and understanding within the society-at-large ...' .

${ }^{12}$ For example, Hungary abolished this distinction only with its 1993 minorities law; the February 1992 draft still maintained the distinction and was withdrawn only following opposition from minority groups (Human Rights Watch/Helsinki, 1996, p. 111).

${ }^{13}$ Italy and Spain continue to deny Roma preferential treatment on a par with that accorded to national minority groups, despite the historical presence of large numbers of Roma on their territories (EUMAP, 2002). However, these western European countries were not the focus of the HCNM's attention in 1993.
} 
and communities rather than merely as a generalized social or security concern. At the same time, it reinforced the idea that human and minority rights issues within a given country could be understood consistently with, even as part of, Europe's security architecture.

Finally, the HCNM's report alluded to the importance of involving Roma in policy-making (HCNM, 1993, pp. 9, 14). Though not described in minority rights terms, this constituted implicit recognition of Romani communities' entitlement to a right historically attached to national minority regimes - political participation (FIER, 1999) - and contributed to the development of a new rhetorical approach to Roma as integrated, politically empowered actors.

Still, having issued his report, the HCNM did not follow the situation of Roma systematically; indeed, he made only one public reference to the Roma in the next six years (HCNM, 1994). This may have been due in part to the HCNM's concern about 'involv[ing himself] in only those situations that meet the criteria of the mandate' (HCNM 1993, p. 13). This concern was reflected in his recommendation that 'a point of contact for Roma issues' be created within the office of democratic initiatives and human rights (HCNM, 1993, p. $15)$, with the suggestion that its human rights-based mandate might be more appropriate for addressing the problems faced by Romani communities. Clearly, there were competing visions within European institutions as to whether the problems of Roma were a security issue, a social issue, or a rights issue, or indeed what the proper relationship between security, socio-economic reform, and rights is for policy addressing marginalized groups.

Indeed, it is worth asking why European institutions approached the HCNM about a migration problem unrelated to conflict in the first place. Seeing a problem, but seeing also that it related to an ethnic group, the OSCE turned to the one institution dealing expressly with minority issues. In so doing, what had initially been primarily a concern about migration was in part transformed into, or at least addressed as, a human rights issue. Despite the HNCM's mandate conservatism, he did address the issue, establishing a set of institutional and rhetorical expectations about migration and minorities. In 2000 he returned to this question.

\section{The HCNM Report of 2000}

By 2000 the context within which the HCNM was operating had changed dramatically. The EU enlargement process had replaced the OSCE and $\mathrm{CoE}$ at the centre of debates about the eastward expansion of Europe, and an at least rhetorical commitment to 'common values' and integration appeared to have replaced the preoccupation with security and the potential for ethnic conflict 
that had dominated the early 1990s. ${ }^{14}$ The genesis of the 2000 report reflects this change in context. In contrast to the 1993 report, presented as the fulfilment of an assignment from the committee of senior officials, the HCNM offered this justification for undertaking the 2000 report of his own volition:

As time passed, I noted in many parts of Europe the persistent plight of the Roma and Sinti ... [who] were generally left outside the scope and beyond the reach of progressive developments. Moreover, the persistence of raciallymotivated hatred and violence directed against the Roma and Sinti can only be considered a blight on the records of individual participating States and of European society in general. ... My intention in embarking upon this study was ... principally to raise the awareness of policy makers to the particular situation and needs of Roma and Sinti, to focus debate on their conditions, and to offer some general recommendations ... I hope that in the new millennium all OSCE participating States will prove fully responsive to the needs of Roma and Sinti and wholly respectful of their rights. As a community of values, the OSCE must assure this for all. (HCNM, 2000, emphasis added)

Concerns about whether or not the situation of Roma fell within his mandate evidently did not prevent the HCNM from revisiting the issues he had raised in 1993. But his justification also suggests two important changes marked by the 2000 report: in geographic focus, and in the balance between security and rights. The 2000 report explores the situation of Roma and Sinti in "many parts of Europe' - that is, in western Europe as well as the CEE region. By 2000 the HCNM was asserting that 'discrimination and exclusion are fundamental features of the Roma experience' and that all OSCE Member States, 'as a community of values' had a democratic obligation to take corrective measures on human rights grounds (HCNM, 2000, Foreword 1).

The HCNM's 2000 recommendations also offer a comprehensive vision of individual and minority rights, calling for more effective protection against racial violence and discrimination, as well as opportunities to cultivate a distinct Romani identity. The HCNM refers to OSCE documents to bolster his recommendation that Roma be integrally involved, as Roma, in developing policies that affect them (HCNM, 2000, pp. 7-9). And although there is much more discussion of rights, there is no reference to migration..$^{15}$

The difference in tone and substance is striking - the 2000 report is 175 pages long, as compared to just 18 pages in $1993^{16}$ - begging the question of

\footnotetext{
${ }^{14}$ The broader security situation had changed dramatically: in 1993, war was still raging in Bosnia and the Transdniestria conflict had only recently subsided. By 2000, the former Yugoslavia was largely at peace, and the geopolitical uncertainty of the immediate post-cold war had receded considerably.

${ }^{15}$ Perhaps as a corollary to this, the 2000 report also places relatively less emphasis on socio-economic issues; one commentator refers to the report's 'reluctance to examine economic aspects of the Roma as a policy subject' (Kovats, in Guy, 2001, p. 99).

${ }^{16}$ The United States Department of State provided substantial funding to support research for the 2000 report, which may in part explain its greater length.
} 
what had changed. Was Roma migration really no longer an issue? Had human and minority rights been accepted as an integral component of an expanded notion of security? And had ensuring a better situation for Roma really become a requirement for membership of the European community of values?

\section{From 1993 to 2000: The Dynamic between Rhetoric and Policy}

To answer these questions, we should consider the divergent policy approaches advocated by EU institutions during the period of these reports. These approaches - human rights implementation, socio-economic investment, and migration prevention - appear on a spectrum from highly rhetorical value commitments to the rational defence of interests.

First, the Copenhagen criteria were adopted in June 1993, at the same time as the HCNM was working on his first report. The choice to identify political criteria including 'respect for and protection of minorities' as a condition of accession placed the EU in a delicate position: candidates were to be measured against a standard of minority protection for which there was no foundation in EU law, no definition, no monitoring mechanism, and widely varying practice between Member States (Hughes and Sasse, 2003, pp. 12-13). Nevertheless, once set, this criterion somehow needed to be assessed for candidates to gain admission to a community that itself neither knew what the standard meant nor applied it to its own members.

Perhaps cognizant of these difficulties, the Commission asserted in the first regular reports on progress towards accession in 1998 that the political criteria had been met in nine of the ten CEE candidates. ${ }^{17}$ Although "meeting the criteria' implied a one-time assessment, the Commission continued to monitor candidates on minority protection and the other criteria. The $1999 \mathrm{ac}-$ cession partnerships specified 'integration' of Roma as a priority for Bulgaria, the Czech Republic, Hungary, Romania and Slovakia, ${ }^{18}$ and the Commission devoted a considerable part of its regular reports' 'minority rights' section to Roma, detailing infringements of their civil, political, economic and social rights, but making no reference to migration.

Second, in 1998 the Directorate-General on Enlargement began allocating significant assistance to 'Roma minorities programmes', primarily in Bulgaria, the Czech Republic, Hungary, Romania and Slovakia, through its Phare programme ${ }^{19}$ Presumably, this funding was intended to support candidate states in addressing some of the problems identified in the regular reports. However,

\footnotetext{
${ }^{17}$ Slovakia did not receive a positive assessment until 1999, after the Mečiar government had lost power.

${ }^{18}$ See accession partnerships at «http://www.europa.eu.int/comm/enlargement/pas/aps.htm».

${ }^{19}$ These were the five candidates with the largest Roma populations. 'Integration of Roma' had been identified as a priority in the accession partnerships concluded in 1999. Phare also supported programmes for the Kirtimai Roma community in Lithuania.
} 
rather than dealing with minority protection or rights, 'most Phare programmes were developed as socio-economic interventions designed to deal with some aspects of the social exclusion experienced by many Roma minority populations' (European Commission Evaluation Unit, 2004, p. 1). A significant percentage of Phare funding supported equipment purchases or infrastructure development (particularly in isolated Romani communities) or 'social integration' (European Commission Evaluation Unit, 2004, pp. 63-4).

The EU's evaluation criticizes Phare programmes' lack of a 'well-informed, clear vision or goal to define exactly what Roma inclusion means and how this will be achieved'; the Phare programmes appear to have been developed without reference to the CoE and HCNM's rights-based articulations of Romani interests. Overall, the Phare programme's funding pattern suggests an identification of Roma minority issues with socio-economic concerns and a persistent if unvoiced preoccupation with migration - a conclusion supported by the comments of CEE officials ${ }^{20}$ and parallel patterns of bilateral assistance. ${ }^{21}$

Third, migration concerns surfaced more openly within the Commission's Directorate-General on Justice and Home Affairs (JHA), which channelled considerable assistance to candidate states to tackle customs, border security and control, and migration issues. For example, between 1998-2002 the Odysseus programme funded a range of exchanges, training and research projects on asylum and immigration, ${ }^{22}$ including an examination of 'Current Irregular Migration of Roma to the Member States' by the International Centre for Migration Policy Development (ICMPD). ${ }^{23}$

That project's report reveals persistent concerns about Roma as migrants. The project was motivated by the 'increased number of asylum requests by citizens from European states that are considered to be safe and are to become EU Members' and aimed to

analyse the background to these recent flows ... to find out which measures can be taken to avoid them and how to react when they take place, without

\footnotetext{
${ }^{20}$ The Czech Human Rights Commissioner suggested this reading of EU motivation in supporting a policy to improve the situation for Roma: 'It can be expected that the result of this social edification of the hitherto marginalised Romany community and the gradual formation of an emancipated Romany minority will lead to a perceptible fall in Romany migration to European Union countries' (cited in Vermeersch, 2003, p. 24).

${ }^{21}$ For example, a government programme to improve the situation for Roma in the Małopolska region of Poland stated that: 'the situation of Roma in Central and Eastern Europe is a matter of special interest to European institutions and the European Member States, which results mainly from fears of migration. This was clearly demonstrated in bilateral contacts with, inter alia, British, Finnish and Irish authorities during the last two years' (Ministry of Internal Affairs and Administration, 'Pilot Government Programme for the Roma Community in the Małopolska Province for the years 2001-2003', February 2001, cited in EUMAP, 2001, p. 378, fn. 159).

${ }^{22}$ See «http://www.europa.eu.int/comm/justice_home/project/odysseus/index_en.htm».

${ }^{23}$ The project also received funding from the governments of Norway, Switzerland and the UK (see ICMPD, 2001, p. 4; Commission Report to the Parliament, 2000, p. 51).
} 
compromising the existing asylum procedures or putting a strain on relations with Candidate States by imposing visa obligations. (ICMPD, 2001, p. 4)

The ICMPD report suggests that Roma were migrating 'mainly for economic reasons ... and therefore host countries regard this to be an abuse of the asylum system, ${ }^{24}$ and regrets the 'damag[e] to the EU association process' caused by the resulting imposition of visa regimes on migration-producing countries. Improving the situation for Roma is presented as a means of eliminating the "push factors' that contribute to migration (ICMPD, 2001, p. 36). The report suggests that restrictive policies are necessary and justified to deter bogus asylum applicants (pp. 19-25), but downplays possible human rights implications. ${ }^{25}$ Consistent with the report's logic, migration concerns have led individual EU Member States to adopt highly restrictive immigration policies clearly aimed at discouraging the entry of Roma. ${ }^{26}$ Around the time the 2000 HCNM report was issued, then, Roma migration continued to be a concern for many Member States - a concern that could trump human rights.

Thus perhaps the greatest shift between 1993 and 2000 was towards a compartmentalization of functions and an increased rhetorical sophistication, rather than any consensus on the underlying conceptualizations of policy. European institutions recognized Roma as a minority, referred to the rights dimension of their situation, and responded to the socio-economic marginalization of Roma with increased investment. ${ }^{27}$ Yet to the extent that they continued to migrate westwards, or were thought likely to, Roma were still seen as a 'problem', albeit one preferably resolved by persuading them to stay where they were rather than by resort to explicitly anti-immigration measures that could damage the EU's image as a 'community of values'.

\footnotetext{
${ }^{24}$ For a contrasting view, see CoE (1999, paras 51-2), noting that migration of Roma is spurred by both 'a strong attitude of non-confidence and non-identification with the majority and its institutions in the respective countries of origin' and 'strong external features ... such as organised and repeated hostilities, single acts of violence ..., or change of status due to the emergence of new states or new citizenship provisions'. It emphasizes that Roma migration is 'proportionally no higher than the average migration to Western Europe [from CEE] countries'.

${ }^{25}$ For instance, the report comments on the 'dramatic' effect (in terms of decrease in asylum applications) of the deportation of 74 Romani asylum-seekers from Belgium in October 1999, but does not mention that this occurred despite a request for a stay by the European Court of Human Rights. In 2002, the Court ruled that the deportation had violated the European Convention on Human Rights (ECHR, 2002).

${ }^{26}$ For example, in 2001, the British Home Office concluded an agreement with the Czech government allowing 'pre-screening' of passengers by British immigration officials in Prague's airport to turn back suspected asylum claimants; one investigation found that Roma were 400 times more likely to be turned back. The Law Lords ruled that this system 'was inherently and systemically discriminatory on racial grounds against Roma, contrary to section 1(1)(a) of the Race Relations Act' (House of Lords, 2004). Interestingly, the HCNM, in his 1993 report, had anticipated that this type of problematic situation might arise (HCNM, 1993, p. 13).

${ }^{27}$ The European Council at Tampere signalled support for the HCNM's recommendations by adopting them together with the recommendations of the CoE's specialist group, giving them added weight in EU policy and programming (Cocen Group, 1999).
} 
These factors point up a disjunction between the EU's rhetorical commitments, on the one hand, and its motivations in allocating resources to prevent migration, on the other. Similarly, its insistence on respect for minority rights in candidate states was not grounded in internal EU standards and policies, which contradicted its commitment to common values. The 'cognitive dissonance' created by this disjunction may have undermined the legitimacy and efficacy of EU policies towards minorities and Roma in particular. ${ }^{28} \mathrm{As}$ the day of accession grew closer, the question became increasingly salient of what would happen when candidates were transformed into members - and their Romani populations into citizens - of an EU with no clear policies for minority protection.

\section{The EU: Migrating towards a Union Minority Policy}

Civil society groups and Romani leaders have seized on the gaps between rhetoric and reality to press for a more coherent minority protection policy, inside and outside the Union. Having put the issue of minority protection on the agenda for accession, EU states were in effect 'entrapped' (Schimmelfennig, 2001), finding it embarrassing not to look at these issues within the EU. Indeed, the draft Constitutional Treaty incorporated the Copenhagen minority protection criterion for all Member States (Draft Constitutional Treaty, 2003, Art. I-2). In a sense, this 'entrapment' represents the unexpected consequences of an idea, yet this was not merely rhetoric shaping reality: without the underlying interest in security - concerning migration but also the integrity of the inter-state project - and the existence of other European norms of process and equality, the rhetorical pull of minority protection might well have faded with accession. Even now, the normative pull of minority rights within the EU is limited in scope. ${ }^{29}$

Yet despite the tensions between security, socio-economic and rights perspectives, with the publication of the HCNM's 2000 report, Roma and other minorities acquired powerful rhetorical tools to argue for their claims as communities. Rights organizations were able to articulate the case for minority protection in terms of process and basic fairness: if respect for and protection of minorities was a criterion, its substance in law and policy would have to be articulated. If minority protection was to be applied in candidate states as a criterion of membership, why not in members as well? Would not ongoing

\footnotetext{
${ }^{28}$ See Schimmelfennig (2001). Many commentators have questioned the extent to which the emphasis placed on improving the situation for Roma in the accession process has in fact led to meaningful improvements in most CEE Romani communities (see HCNM, 2000; EUMAP, 2002; Kovats, 2003; Guy, 2001).

${ }^{29}$ Contrast the limited commitment to minority protection in the draft Constitutional Treaty with the strong anti-discrimination standards of the race equality directive of 2000 . 
monitoring to forestall backsliding be of use in Member States as well as candidates $?^{30}$

Some Roma political and community leaders pressed critiques mobilizing these various policy strands to address institutional concern about migration with a distinct orientation towards rights; for example the 2003 collective declaration of Romani associations noted that:

migration is often a sign and symptom of a lack of equal opportunity at home, in terms of education, employment, housing, health, credit and public services. We note lately manifestations of discrimination against Roma in both their home countries and 'host countries' concerning the freedom of circulation in the time of an $[s i c]$ unified Europe. Rules established between candidate countries and Member States of the European Union are applied in a discriminatory way. If we agree with combating illegal migration, this kind of migration, which is not so widespread among Roma, only could be reduced when the livelihood of all citizens is guaranteed at home. We recognise racism and discrimination as the underlying cause of the inequality suffered by Roma across Europe. (Collective Declaration, 2003)

This kind of critique unites calls for equal process across the European space with concerns about economic conditions and exclusion. Moreover, in the declaration Romani activists stake claims not for economic transfers but for initiatives to promote social integration and 'stronger effort to fully involve Roma in democratic processes' (Collective Declaration, 2003, Point 3). ${ }^{31}$ The move by Romani leaders to include rights claims alongside resource transfers was not solely a product of policy disputes between European elites. To be sure, the increased activism of Romani organizations since the end of the communist period might well have proceeded - and focused on Europe and discrimination - without the rhetorical tensions created by European institutions' parallel policies $;^{32}$ indeed, Romani activism itself helped channel the focus and activities of European institutions. ${ }^{33}$ Yet the tensions arising out of the accession project probably increased the scope of action for Romani

\footnotetext{
${ }^{30}$ See, e.g., EU Network of Independent Experts (2003, p. 174) (criticizing the failure of Member States to ratify the Framework Convention for the Protection of National Minorities 'although according to the criteria of Copenhagen, the ratification of the Framework Convention is a condition imposed on the States who have applied to join the European Union') (EUMAP, 2002, Overview).

${ }^{31}$ The declaration calls for: funding for legal representation, voter education and registration; integration of Roma into mainstream media and expansion of Romani press centres; support for Roma to study law; and Romani universities (Collective Declaration, 2003, Points 1, 3, 4, 5, 6a-b).

32 'Roma activists and intellectuals are beginning to work together to create a network of groups and organisations which can tap into the corridors of power in the European Union in an effort to improve the social, economic and political situation of Roma in Europe' (Gheorghe, 1991, pp. 840-4, cited in Clark).

${ }^{33}$ See, e.g., Russinov (2002, pp. 188-90), discussing interactions with the Council of Europe and the European Roma Rights Centre in the work of a Roma coalition to define anti-discrimination policy in Bulgaria.
} 
groups, and over time it defined the most productive and compelling forms their message could take.

Institutional actors were also aware of the problems a double standard posed and the opportunities it created for change within the Union. In 2002, the $\mathrm{HNCM}^{34}$ noted that accession's normative commitments had improved the position of minorities in the candidate states and that these commitments could not be confined to the accession period:

[O]ver the past decade, the incentive of living up to the Copenhagen criteria has been an important impetus for the governments of applicant States to adopt or improve policies and laws to protect and promote the rights of persons belonging to national minorities. ... This leads me to a point which I believe needs to be seriously considered. ... What are the EU's own standards when it comes to the protection of national minorities? It is clear that the Copenhagen criteria are important for clearing the bar to get into the EU, but what happens when you have passed that hurdle? Do the rules change? Surely the standards on which the Copenhagen criteria are based should be universally applicable.... Otherwise, the relationship between the existing and aspiring EU Members States [sic] would be unbalanced in terms of applicable standards. I believe such an imbalance would also be inconsistent with declared EU values and raise serious doubts about the normative foundations of the EU itself. (HCNM 2002, p. 4)

Prior to the accession process, these 'normative foundations' had not encompassed minority protection. Externally oriented security concerns prompted the initial pronouncement of minority protection; internally oriented norms of equality subsequently made it difficult to prevent minority protection from encompassing Member States as accession became an imminent reality. Once the new states joined, the Union's own logic required they not be subject to radically different norms, but the only other coherent solution - abandonment of the Copenhagen criteria - would have made the double standard all too apparent and risked the gains minority protection outside the Union were thought to have achieved. Instead, progressive extension of minority protection norms to all Member States provides a way to meet the concerns of various actors: those concerned with migration as a security issue, those with rights or socio-economic orientations, and those concerned with the EU's integrity as a normative project.

\section{The Migration of Policy after Accession}

Concern with migration drove much of European policy towards Roma in the 1990s. Yet with accession, the social, rights, and security issues surrounding

\footnotetext{
${ }^{34}$ Rolf Ekeus replaced Max van der Stoel as HCNM in July 2001. 
Roma became internal issues. ${ }^{35}$ With accession, a Union whose members had gone to great lengths to restrict Roma migration now on a single day admitted over a million Roma, who have become both citizens of the Union and members of its largest minority. Even if Europe has principally been concerned with Romani migration, with accession it has become apparent that a migration model is insufficient. The EU's fundamental equality norms mean that simply by staying where they are - and in the conditions in which many of them live - Roma have become a concern for an EU that has come to them.

Movement of Roma from one EU Member State to another is now difficult either to restrict or to classify as a 'problem', since that movement is protected by fundamental EU norms (Braham and Braham, 2000, pp. 105-10). Yet, while accession has altered the legal and political framework of possibility relating to minorities and migration, it has not altered the underlying security and social integration concerns that drove pre-accession policy. Since accession has made direct restrictions on migration by EU citizens all but impossible, the tools available to address continuing concerns about Roma migration have changed, though the concern has not. ${ }^{36}$

For example, during the accession period several Member States took measures to restrict asylum applications by Roma from CEE countries. With accession, freedom of movement makes asylum moot, and in any event an asylum claim originating in another Member State would represent a serious crisis for the Union, since it would necessarily imply a failure to uphold the core political criteria underpinning membership. ${ }^{37}$ Yet the underlying socioeconomic situation and rights of Roma in the CEE states have not necessarily improved - these issues have been internalized with no new mechanism being put in place to respond to them except the norms of minority protection (Braham and Braham, 2000, pp. 106-10). Thus, the fact that the UK can no longer deny immigration to Czech Roma ${ }^{38}$ or that Belgium cannot return Roma asylum applicants (Cahn and Vermeersch, 2000) does not mean that the perceived economic burdens, social disruptions or security concerns underlying earlier restrictions will not sound in domestic British or Belgian policies. Accession

\footnotetext{
${ }^{35}$ Transitional restrictions on free movement will continue, but with a clear timeline for their termination, after which CEE citizens will have identical movement rights as other EU citizens (see Rigo, 2005, pp. 16-17).

${ }^{36}$ This concern is not necessarily well founded. Only 15 per cent of migrants into the EU since 1989 have been from the CEE states (Zielonka, 2001, p. 520), and migration of Roma has not been significantly higher than that of non-Roma (Matras, 2000, p. 47). There is also reason to suppose westward migration will not dramatically increase with accession (Kraus and Schwager, 2003).

${ }^{37}$ The concept that EU membership makes asylum claims moot presupposes a minimum level of common political commitment by each Member State; failure to meet such a minimum could elicit a response by the EU or other Member States, as happened with Austria after the Freedom Party entered government.

${ }^{38}$ As noted above, the Law Lords have recently held against this practice on human rights grounds (House of Lords, 2004) but, even if they had not, it would have been unavailable as a matter of policy after accession.
} 
has limited members' options for excluding Roma at their borders, but the concerns that motivated such policies will persist and seek other outlets. ${ }^{39}$

Even if Roma do not migrate, their exclusion and impoverishment pose different policy challenges for a Union that must now deal with them as citizens and minorities. Roma populate the whole taxonomy both of minorities - cultural, social, political - and of migrants - political, economic, and (for those from outside the EU) illegal. ${ }^{40}$ The development of minority policy, at least as regards Roma, was governed by a particular conjunction of persistent concerns about migration and the implications of impending citizenship for large numbers of Roma, and it is not clear that the lesson is replicable for true migrant groups. The many connections between migrant and minority - the sense of difference, the fact that migrants often form new minorities - coexist with a practical hierarchy between the two, a passage from an impermanent, marginal status to membership. For all the problems that attach to minority status, it is often an improvement on the prospects confronting the migrant. We may expect some members of recent migrant communities, such as Muslims, to resist being consigned to a 'permanent migrant' status. The project of integrating different communities is still very much seen as a security issue for the Union; in the same speech in which he discussed the need for common norms, the HCNM warned of the dangers should such normative integration fail:

[D]iscrimination, racism, intolerance and xenophobia not only persist across Europe, but in some cases are gaining strength. It is also clear that such ideas remain powerful mobilizing agents for populists, and that EU membership provides no immunity in this regard. In particular, religious intolerance - especially anti-Semitism and Islamophobia - have not abated and could open fissures within our societies. These are issues that Europe must address in order to prevent intra-State cleavages from cracking the bigger inter-State project. (HCNM, 2002, p. 7)

\section{Conclusion: A Balanced Policy for the Union?}

Contrary to many observers' expectations, it is the Union that has migrated, while most Roma have stayed where they are. What would constitute a policy responsive to the range of concerns - security, social integration, equality, human and minority rights, the Union's integrity - that the continuing social and economic exclusion of Roma implicates? Many observers critical of anti-migration policies tend to advocate either a rights-based or a socio-

\footnotetext{
${ }^{39}$ These policy instruments will still be available against Roma or other migrants from non-Member States, which are likely to continue to be seen predominantly as a security concern and treated as such. Concern with mass immigration has encouraged discrimination in old Member States, and can be expected to do the same in the CEE states as they increasingly receive migration as well as produce it (Mudde, 2005, p. 184).

${ }^{40}$ See taxonomies outlined in the introduction to this special issue. 
economic alternative. Yet, it seems clear that rights, investment and security are interrelated, and that a single-minded focus on any one aspect in isolation is insufficient and may actually produce harmful policy outcomes. Exclusive concern with security can excuse abuses of communities already pressed to the margins, yet ignoring societies' legitimate concern with stability and prosperity in the face of population movements or assertions of difference is not realistic either. Similarly, relying on humanitarianism to underpin human rights or social investment may not be as effective as linking those policies to a security interest in restricting migration; on the other hand, securitizing social and rights commitments can reduce support for them when the underlying security concerns are met. There are also perverse incentives in an unbalanced approach: for example, favouring collective rights over investment could lower the financial cost of addressing Romani issues, while delivering fewer economic goods to individual Roma who confront both discriminatory exclusion and poverty.

An exclusive focus on collective rights risks ghettoizing Roma politics, reducing access to public services and excluding Roma from effective participation. It could provoke a reaction from majorities if funding is earmarked for the minority. Identifying all Roma as a single community may be a rational policy choice, but Roma from different parts of Europe have highly diverse languages and cultures, and it would not be obvious to many Roma communities that they share a single identity; many would oppose homogenization (Marushiakova and Popov, in Guy, 2001, pp. 33-50). Conversely, collective politics could give Roma greater bargaining power, and the social marginalization Roma already suffer is so pervasive that it is not clear further ghettoization would occur.

A balanced policy would have to address the high unemployment, low education and socio-economic marginalization that affect Roma. Even if pervasive majority prejudice could be reversed, individual Roma would still be in extremely disadvantaged positions demanding attention and investment from EU institutions whether or not they move west. Yet the socio-economic problems confronting Roma, important as they are, cannot be separated from that broader context of pervasive discrimination (Waters and Guglielmo, 1996, p. 297). It is an open question if any policy can affect discriminatory attitudes, yet precisely because there is little reason to think that majority attitudes can be ameliorated in the near term, we believe that increased support for political participation by Roma, as Roma and citizens, holds the most promise of effecting change and combating harm. Politically empowered communities are better able to define and defend their own interests, even in absence of agreement on effective policy measures (Piana, 2004, pp. 34-6). Alongside rights commitments, therefore, such a policy would prioritize investments in effective political participation, such as literacy and education, rather than in 
wealth creation. Given the determinative role of majority prejudice, an effective policy would also have to begin to identify common interests in security and in the success of the integrative Union project, by seeking to demonstrate to majorities their interest, with minorities, in protection of cultural differences and in assuring each community's participation in policy-making within a Union that has no majority.

In practice, this 'constitutive and participatory approach' implies greater attention to constructing policy in co-ordination with minority communities, an approach embodied in the recommendations of the CoE's specialist group, which emphasize the importance of Romani involvement in community affairs, rights monitoring, political processes and institutions (CoE, 1999, paras 57-9). ${ }^{41}$ Those recommendations also note that efforts to 'prevent ... the causes of migration ... need to concentrate more specifically on conflict prevention if they are to remove the causes for non-confidence and non-identification of Roma in mainstream societies in the countries of origin' (CoE, 1999, para. 54). A balanced policy thus has to combat prejudice, promote investment in Romani individuals and communities, and support collective identity and participation. Yet it will have to do so in a fashion not principally motivated by a desire to suppress migration.

The 1993 HCNM report suggests a European policy preoccupied, not with ameliorating socio-economic marginalization for the sake of excluded populations, or even for the health of the societies in which they live, but with forestalling undesired migration for the sake of the recipient countries. Whatever rhetorical and policy shifts we may identify in the $2000 \mathrm{HCNM}$ report, there is little indication that this preoccupation has changed (Matras, 2000, p. 47). It is an interesting theoretical question how much intentionality matters in policy formulation, but common sense suggests that underlying intentions may affect resource commitments at the margins in policy implementation.

Rhetorical-action or deliberative theories suggest that actors' choices produce outcomes that lower the cognitive dissonance between their public commitments and their individual preferences (Schimmelfennig, 2001; Neyer, 2003; Piana, 2004). If this is right, the process is surely iterative: not only policy, but understandings of the purposes of policy and its implementation are shaped in this fashion. When the implementation of a policy itself comes into tension with public value commitments, cognitive dissonance will generate another round of adjustment. Over time, it is difficult to imagine that investment policies whose effective purpose is to discourage exercise of a right of free movement will always choose what is best for the flourishing of individuals and communities, rather than what is best for discouraging their movement.

\footnotetext{
${ }^{41}$ The specialist group is led by and has substantive participation by Romani experts.
} 
Whatever their formal consistency with the acquis communautaire, policies designed to discourage freedom of movement do not seem compatible with the fundamental commitments, the 'common values,' of the Union. At the least, such policies suggest a different Union, one in which identity and community are protected as much by separation as by integration. That may be an acceptable vision - and many aspects of the present European project suggest it is - but it may not serve the interests of individuals and communities such as the Roma who do not form a majority in any one Member State.

There is reason to expect that minority protection will remain on the agenda and increasingly be interpreted as a rights issue, albeit one with an important security and integrative component. The concerns that led Member States to elevate minority protection to a priority of the Union in the early 1990s combine with the logic and processes of membership to create an opening for minorities to advance their agenda in a way states will find difficult to contain. Minority rights, like rights generally, have proved a rhetorical stimulus to policy change. As Landau (2004) argues:

The EU cannot remain ambiguous forever, because an integrated Europe precisely requires new understandings of how states and societies relate to each other. It may take several years before the EU is pushed to standardize minority rights, but the seeds of minority activism at the supranational level have already been planted by currently vague strategies of interpreting and implementing minority rights. ... [T] he more groups that are incorporated under EU auspices and the more diverse the European Union becomes, the more difficult it will be to ignore the gap between minority rights rhetoric and state's obligations to uphold minority rights.

Given the seriousness of the problems Romani communities throughout Europe continue to confront, rhetorical and conceptual advancements may seem cold comfort. Yet precisely because the real solutions to the problems that confront Roma may lie, not in anti-discrimination directives, social investment strategies, or the articulation of rights, but in changing attitudes among majorities, the change may be critical: no longer seen and spoken of as if they were migrants, Roma may finally be arriving as European minorities.

\section{Correspondence:}

Rachel Guglielmo

Director, Public Health Watch

Open Society Institute

400 W. 59th Street

New York, New York 10019, USA

Tel: +1 9176406394 Fax: +1 2125484610

email: rguglielmo@sorosny.org
Timothy William Waters

Visiting Professor

University of Mississippi Law School

Lamar Law Center Room 543

Oxford MS 38677

Tel: +1 6623800320

email: timothy.waters@post.harvard.edu 


\section{References}

Braham, M. and Braham, M. (2000) 'Romani Migrations and EU Enlargement'. Cambridge Review of International Affairs, Vol. 13, No. 2, pp. 97-116.

Cahn, C. (ed.) (2002) Roma Rights: Race, Justice, and Strategies for Equality (New York: International Debate Education Association).

Cahn, C. and Vermeersch, P. (2000) 'The Group Expulsion of Slovak Roma by the Belgian Government: A Case Study of the Treatment of Romani Refugees in Western Countries'. Cambridge Review of International Affairs, Vol. 13, No. 2, pp. 71-82.

Capotorti, F. (1979) 'Study of the Rights of Persons Belonging to Ethnic, Religious and Linguistic Minorities'. Doc. E/CN. 4/Sub. 2/1979/384 (Geneva: United Nations).

Clark, C. 'Counting Backwards: The Roma "Numbers Game" in Central and Eastern Europe'. Patrin Web Journal, available at «http://www.geocities.com/Paris/5121/ countingback.htm».

Cocen Group (1999) Guiding Principles for improving the situation of the Roma based on the recommendations of the Council of Europe's Specialist Group on Roma/Gypsies and on the recommendations of the OSCE High Commissioner on National Minorities, adopted by the European Union (Cocen Group) at the Tampere summit, December, available at «http://www.CoE.int/T/DG3/RomaTravellers/documentation/recommendations/MiscCOCENguidelineseu_en.asp».

CoE (1992) Charter for Regional or Minority Languages.

CoE(1993) Parliamentary Assembly Recommendation 1201 on an additional protocolon the rights of national minorities to the European Convention on Human Rights.

$\mathrm{CoE}$ (1999) 'Problems arising in connection with the international mobility of the Roma in Europe and the recent emigration of Roma from the Czech Republic and the Slovak Republic' (two reports by Dr Yaron Matras for the European Committee on Migration, December 1996 and August 1998), adopted CDMG 41st meeting, 1-3 December, MG-S-ROM (2000).

Collective Declaration (2003) 'Collective Declaration of Romani Associations adopted by Romani NGOs during the Preparatory Meeting Held on 9-10 April 2003 in Vienna, Organised by Romano Centro'. OSCE-ODHIR, Report, OSCE Supplementary Human Dimension Meeting on Roma and Sinti, Vienna, 10-11 April, available at «www.osce.org/documents/odihr/2003/09/681_en.pdf».

Commission of the European Communities (2000) 'Third report of the Commission to the European Parliament and the Council on the implementation of the ODYSSEUS and the FALCONE programmes'. SEC (2001) 903.

Commission of the European Communities DG Enlargement, Directorate E Evaluation Unit (2004) 'Review of the European Union Phare Assistance to Roma Minorities'. Report ZZ/MIN/03082, 9 December.

Copenhagen Criteria (1993) Conclusions of the Presidency. European Council, Copenhagen, 21-2 June, SN 180/93. 
Council of the European Community (1991) 'Declaration on the Guidelines on the Recognition of New States in Eastern Europe and in the Soviet Union'. International Legal Materials (1992), p. 1485.

Crowe, D. (1994) A History of the Gypsies of Eastern Europe and Russia (New York: St. Martin's Press).

Crowe, D. and Kolsti, J. (eds) (1991) The Gypsies of Eastern Europe (Armonk: E.C. Sharpe).

CSCE (1990a) Charter of Paris for a New Europe, 19-21 November (Paris:Conference on Security and Co-operation in Europe).

CSCE (1990b) Document of the Copenhagen Meeting of the Conference on the Human Dimension of the CSCE, 5-29 June, available at «http://www.osce.org/ docs/english/1990-1999/hd/cope90e.htm» (Paris: Conference on Security and Co-operation in Europe).

CSCE (1991a) Document of the Moscow Meeting of the Conference on the Human Dimension (Paris: Conference on Security and Co-operation in Europe).

CSCE (1991b) Report of the Geneva Meeting of Experts on National Minorities (Paris: Conference on Security and Co-operation in Europe).

CSCE (1992) Helsinki Document: The Challenges of Change (Paris: Conference on Security and Co-operation in Europe).

Draft Constitutional Treaty (2003) Draft Treaty establishing a Constitution for Europe, adopted by consensus at the European Convention on 13 June and 10 July, submitted to the President of the European Council in Rome, CONV 850/03, Brussels, 18 July.

EU Network of Independent Experts (2003) EU Network of Independent Experts in Fundamental Rights (CFR-CDF), Report on the Situation of Fundamental Rights in the European Union and its Member States in 2002, 31 March.

EUMAP (2001) European Union Accession Monitoring Program Monitoring the EU Accession Process: Minority Protection (Budapest: Open Society Institute).

EUMAP (2002) European Union Accession Monitoring Program Minority Protection in EU Member States (Budapest: Open Society Institute).

European Council (1992) Declaration on Principles of Governing External Aspects of Migration Policy, SN 456/92, Annex 5 to Part A (Conclusions of the Presidency, Edinburgh, 12 December, available at «http:www.europarl.eu.int/summits/edinburgh/a5_en.pdf»).

European Court of Human Rights (2002) Case of Čonka v. Belgium (Application no. 51564/99) Judgment. Strasbourg, 5 February.

European Roma Rights Centre (1996) Divide and Deport: Roma and Sinti in Austria (Budapest: ERRC).

European Roma Rights Centre (2000) Campland: Racial Segregation of Roma in Italy (Budapest: ERRC).

European Roma Rights Centre and Greek Helsinki Committee (2003) Cleaning Operations: Excluding Roma in Greece (Budapest: ERRC).

FIER (1999) Foundation on Inter-Ethnic Relations The Lund Recommendations on the Effective Participation of Minorities in Public Life (The Hague: FIER). 
Fraser, A. (2000) 'The Present and Future of the Gypsy Past'. Cambridge Review of International Affairs, Vol. 13, No. 2, pp. 17-31.

Guy, W. (ed.) (2001) Between Past and Future: The Roma of Central and Eastern Europe (Hatfield: University of Hertfordshire Press).

Hancock, I. (1999) 'The Roma: Myth and Reality'. Patrin Web Journal, available at «http://www.geocities.com/Paris/5121/mythandreality.htm».

Hannum, H. (1990) Autonomy, Sovereignty and Self-Determination: The Accommodation of Conflicting Rights (Philadelphia: University of Pennsylvania Press).

HCNM (1993) 'Roma (Gypsies) in the CSCE Region'. Paper presented to the Meeting of the Committee of Senior Officials, 21-3 September.

HCNM (1994) 'Introductory Remarks', at the CSCE Human Dimension Seminar on 'Roma in the CSCE Region'. Warsaw, 20 September. available at «http://www. osce.org/documents/hcnm/1994/09/3471_en.pdf».

HCNM (2000) 'Report on the Situation of Roma and Sinti in the OSCE Area'. Available at «http:// www.osce.org/hcnm/documents/reports/».

HCNM (2002) 'From the Copenhagen Criteria to the Copenhagen Summit: The Protection of National Minorities in an Enlarging Europe'. Conference on National Minorities in the Enlarged European Union, Copenhagen, 5 November.

House of Lords (2004) 'Opinions of the Lords of Appeal for Judgment in the Case "Regina v. Immigration Officer at Prague Airport and another (Respondents) ex parte European Roma Rights Centre and others (Appellants)" ' [2004] UKHL 55, on appeal from [2003] EWCA Civ 666.

Hughes, J. and Sasse, G. (2003) 'Monitoring the Monitors: EU Enlargement Conditionality and Minority Protection in the CEECs'. Journal on Ethnopolitics and Minority Issues in Europe, No. 1.

Human Rights Watch/Helsinki (1996) Rights Denied: The Roma of Hungary (New York: Human Rights Watch).

ICMPD (2001) 'Current Roma Migration from the EU Candidate States: The Scope and Features of Roma Irregular Movements, the Reactions of the Host Countries, and the Effects on the EU Candidate States' (EU Odysseus Programme).

Kenrick, D. (1998) Historical Dictionary of the Gypsies (Romanies) (London: Scarecrow Press).

Kenrick, D. and Puxon, G. (1972) The Destiny of Europe's Gypsies (London: Sussex University Press).

Klimová-Alexander, I. (2005) The Romani Voice in World Politics: The United Nations and Non-State Actors (Aldershot: Ashgate Publishing).

Kovats, M. (2003) 'The Politics of Roma Identity: Between Nationalism and Destitution'. Open Democracy, available at «http://www.openDemocracy.net».

Kraus, M. and Schwager, R. (2003) 'EU Enlargement and Immigration'. Journal of Common Market Studies, Vol. 43, No. 2, pp. 165-81.

Landau, D. (2004) 'Testing the Limits of EU Integration: Minority Rights Ambiguity and the Hungarian Status Law'. Paper presented at the 'First Global Conference "Redefining Europe: Federalism and the Union of European Democracies", Prague, 26-30 March. 
Lucassen, L., Willems, W. and Cottaar, A. (1998) Gypsies and Other Itinerant Groups: A Socio-Historical Approach (New York: St. Martin's Press).

Matras, Y. (2000) 'Romani Migrations in the Post-Communist Era: Their Historical and Political Significance'. Cambridge Review of International Affairs, Vol. 13, No. 2, pp. 32-50.

Mirga, A. and Gheorghe, N. (1997) 'The Roma in the Twenty-First Century: A Policy Paper' (Princeton: PER).

Mudde C. (2005) 'Racist Extremism in Central and Eastern Europe'. East European Politics and Societies, Vol. 19, No. 2, pp. 161-84.

Neyer, J. (2003) 'Discourse and Order in the EU: A Deliberative Approach to Multi-Level Governance'. Journal of Common Market Studies, Vol. 41, No. 4, pp. 687-706.

Piana, D. (2004) 'Constructing European Constitutional Discourse? Arguments for Common Values in the European Convention'. South European Society and Politics, Vol. 9, No. 1, pp. 24-40.

Pogány, I. (2004) The Roma Café: Human Rights and the Plight of the Romani People (London: Pluto).

Pollack, M. (1994) 'Creeping Competence: The Expanding Agenda of the European Community'. Journal of Public Policy, Vol. 14, No. 2, pp. 95-145.

Race Equality Directive (2000) 'Council Directive 2000/43/EC of 29 June 2000 implementing the principle of equal treatment between persons irrespective of racial or ethnic origin'. Official Journal L180/22, 19 July.

Rigo, E. (2005) 'Citizenship at Europe's Borders: Some Reflections on the Post-colonial Condition of Europe in the Context of EU Enlargement'. Citizenship Studies, Vol. 9, No. 1, pp. 3-22.

Russinov, R. (2002) 'The Bulgarian Framework Programme for Equal Integration of Roma: Participation in the Policy-making Process'. In Cahn, C. (ed.) Roma Rights: Race, Justice, and Strategies for Equality (New York: International Debate Education Association).

Schimmelfennig, F. (2001) 'The Community Trap: Liberal Norms, Rhetorical Action and the Eastern Enlargement of the European Union'. International Organization, Vol. 55, pp. 47-80.

Vermeersch, P. (2003) 'EU Enlargement and Minority Rights Policies in Central Europe: Explaining Policy Shifts in the Czech Republic, Hungary and Poland'. Journal on Ethnopolitics and Minority Issues in Europe, No. 1.

Waters, T.W.(1995) 'Kings without Countries: Problems in the Formation of a Gypsy National Identity'. Journal of Public and International Affairs, Vol. 6, pp. 24-46.

Waters, T.W. and Guglielmo, R. (1996) “"Two Souls to Struggle with”: The Failing Implementation of Hungary's New Minorities Law and Discrimination against Gypsies'. Harvard Human Rights Journal, Vol. 9, pp. 297-313.

Zielonka, J. (2001) 'How New Enlarged Borders Will Reshape the European Union'. Journal of Common Market Studies, Vol. 39, No. 3, pp. 507-36. 